\title{
ВЛИЯНИЕ ПРЕДПОСЕВНОГО ОЗОНИРОВАНИЯ СЕМЯН НА ЭФФЕКТИВНОСТЬ ПРОИЗВОДСТВА ЗЕЛЁНОЙ МАССЫ КЛЕВЕРА ЛУГОВОГО
}

\section{А.Н. Сорокин}

к.С.-Х.Н., старший научный сотрудник отдела инновационных разработок в растениеводстве

Т.М. Морозова (фото)

научный сотрудник отдела инновационных разработок

в растениеводстве

ФГБНУ «Костромской научно-исследовательский институт сельского хозяйства», с. Минское

Предпосевное озонирование семян, озоновоздушный поток, клевер луговой, предпосевная обработка, концентрация озона, урожсайность

Presowing seed ozonation, ozone-air flow, meadow clover, presowing treatment, ozone concentration, productivity
Сегодня весьма актуальна проблема применения низкозатратных, низкоэнергоёмких и экологически безопасных технологий в различных отраслях сельского хозяйства, пищевой и перерабатывающей промышленности [1]. Обработка семян растительных культур озоновоздушным потоком - необходимый агротехнический приём в современном сельскохозяйственном производстве, позволяющий увеличивать всхожесть семян, усиливать процессы обмена веществ, подавлять развитие болезней пыльной головни, бурой ржавчины и мучнистой росы, повышать устойчивость к неблагоприятным внешним факторам, формировать более ранние урожаи с лучшими экономическими показателями [2].

Озонирование - один из наиболее прогрессивных современных технологических процессов обработки семян. Основными достоинствами предпосевного озонирования являются: высокий окислительный потенциал, простота и доступность получения озона в электрических аппаратах, экономическая целесообразность, безотходность производства, а также экологическая совместимость озона с окружающей средой. Считается, что озон, применяемый в различных концентрациях, способствует повышению посевных качеств семян и подавлению патогенной микрофлоры. Выявлено положительное влияние озона на подавление грибной инфекции следующих родов: Fusarium, Aspergillus, Penicillium, Alternaria, Rhizopus. Это позволяет ограничить или исключить применение традиционных химических средств предпосевной обработки семян (протравливание семян), которые оказывают отрицательное воздействие на окружающую среду и человека $[3,4]$.

В связи с этим, изучение влияния предпосевного озонирования семян различных сельскохозяйственных культур представляет научный и практический интерес, в том числе и с точки зрения расширения ассортимента культур, на которых возможно применение озони- 
рования. Одной из наиболее распространённых кормовых культур является клевер луговой [5].

Цель исследования - изучение эффективности предпосевного озонирования семян при выращивании клевера лугового.

\section{Материал и методы исследований}

Исследования проводились в ФГБНУ «Костромской НИИСХ» в 2015-2017 гг. Для установления технологических параметров предпосевной обработки семян использовали генератор озона ГОБОС-01, разработанный и изготовленный в ФГБНУ «Костромской НИИСХ» [6]. В основе работы установки лежит принцип получения озона в режиме переменного высокочастотного барьерного разряда между активными и заземлёнными электродами, разделёнными барьерным изолятором. Скорость озоновоздушного потока в загрузочном бункере генератора озона составляла 0,08-0,1 м/с. Концентрацию озона определяли с использованием газоанализатора «Сигнал-4Э».

В исследованиях использовали клевер луговой сорта Сонет. В лабораторных и полевых опытах изучали влияние двух концентраций

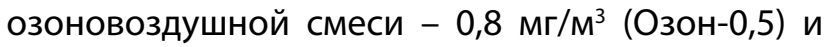
1,5 мг м³ (Озон-1,0) при времени экспозиции 20 минут. Посевные качества семян определяли по ГОСТ 12038.

В исследованиях учитывали фенологические фазы, урожайность и элементы её структуры по методике Н.А. Майсуряна [7]. Полевые опыты закладывали на типичных для региона дерновоподзолистых легкосуглинистых почвах со слабокислой реакцией (pH), средним содержанием фосфора и низким содержанием калия. Насыщенность основаниями повышенная. Агрохимические показатели почвы определяли по общепринятым методикам - $\mathrm{pH}$ солевой вытяжки (ГОСТ 26483-85), гидролитическую кислотность и сумму поглощённых оснований (по Каппену-Гильковицу), гумус (по Тюрину), подвижный фосфор $\left(\mathrm{P}_{2} \mathrm{O}_{5}\right)$ и обменный калий (КО) (по Кирсанову). Клевер подсевали под покров яровой пшеницы. Пло-

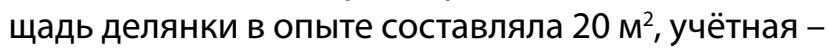
$18 \mathrm{~m}^{2}$, повторность трёхкратная.

Математическая обработка результатов опытов проводилась с помощью программ AGROS 2.02 и Excel 2007 по методике Б.А. Доспехова [8].

\section{Результаты исследований}

Лабораторные опыты показали, что обработка семян озоновоздушным потоком повышает энергию прорастания на 1-13\% и лабораторную всхожесть семян на 0-6\%. Энергия прорастания при обработке семян концентрациями озона

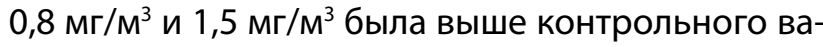
рианта на 13 и 10\% соответственно. Лабораторная всхожесть по вариантам опыта - контроль, Озон-0,5 и Озон-1,0 - 87, 92 и 91\% соответственно. Вариант Озон-0,5 в целом способствовал получению наиболее высоких показателей энергии прорастания и всхожести в сравнении с контролем [9].

Погодные условия в период исследований отличались непостоянством по количеству осадков и температуре воздуха. В 2015 году отмечалось переувлажнение почвы при пониженной температуре воздуха (но близкой к многолетним значениям) во второй половине лета, хотя для появления всходов и начального развития растений условия были вполне благоприятными.

Условия вегетации 2016 года можно в целом охарактеризовать как благоприятные по температуре и количеству осадков. В 2017 году в первой половине вегетации температура воздуха была ниже среднемноголетних значений при избыточном количестве осадков. Так, ГТК июня 2017 года составил 3,3 при среднемноголетнем 1,43. В июле ГТК составил 2,10 (среднемноголетний -1,52) при температуре воздуха, близкой к норме. Август был теплее и засушливее обычного.

В первый год жизни растения клевера развивались быстрее в вариантах с обработкой семян озоном. Так, высота растений в варианте Озон-0,5 была выше, чем в контроле через 10 недель после посева на 1,9 cм, через 12 недель - на 3,1 см, а через 13 недель - на 3,8 см.

Формирование розетки листьев позволяет выявить влияние озонирования на растения клевера лугового первого года жизни. Количество листьев в розетке было наибольшим в варианте Озон-0,5 - 1,65 шт., что на 10\% превышало контроль с 1,5 листьями в розетке. В варианте Озон-1,0 количество листьев в розетке было меньше на 4\%, чем в контроле.

Результаты фенологических наблюдений показали, что предпосевное озонирование семян оказало положительное влияние на высоту клевера лугового сорта Сонет первого года пользования. После укоса определение высоты отрастания клевера 1 года пользования было проведено 9 августа 2016 года, в варианте Озон1,0 она составила 18,6 см. Таким образом, в посевах клевера лугового первого года пользования в варианте Озон-0,5 прослеживалась особенность более дружного развития в первый период роста. 
Вариант с дозой озонирования Озон-1,0 проявил свой потенциал при отрастании после укоса. Таким образом, временем обработки семян клевера можно программировать отдачу урожайности посевами в тот или другой период, что может способствовать формированию заданного «живого конвейера» по укосу трав.

На второй год жизни во все фазы развития доминировал вариант Озон-0,5. В фазу отрастания высота между вариантами опыта была больше на 1,5 см, или на 19,7\%, в фазу стеблевания на 8,7 см, или на $16 \%$, в фазу бутонизации - на 12,2 см, или 12,5\%, чем в контроле [10].
Анализируя урожайность зелёной массы клевера лугового сорта Сонет 1-го и 2-го года пользования, можно отметить положительное последействие предпосевного озонирования семян при обеих концентрациях (табл. 1).

Из таблицы 1 видно, что в 2016 году урожайность зелёной массы клевера лугового при предпосевном озонировании семян в варианте Озон0,5 получена выше на 4,5 т/га, или на $14,6 \%$, а в варианте Озон-1,0 - на 1,5 т/га, или на 4,9\%, чем в контроле. В 2017 году урожайность в варианте Озон-0,5 получена выше на 2,6 т/га, или на 9,4\%, а в варианте Озон-1,0 урожайность получена ниже

Таблица 1 - Урожайность зелёной массы клевера лугового сорта Сонет (в среднем за 2016-2017 гг.)

\begin{tabular}{|c|c|c|c|c|}
\hline \multirow{2}{*}{ Вариант } & \multicolumn{3}{|c|}{ Урожайность, т/га } & \multirow{2}{*}{$\begin{array}{c}\text { Сбор зелёной массь } \\
\text { за } 2 \text { года }\end{array}$} \\
\hline & 2016 г. & 2017 г. & в среднем за 2 года & \\
\hline Контроль & 30,8 & 27,6 & 29,2 & 58,4 \\
\hline Озон-0,5 & 35,3 & 30,2 & 32,7 & 65,5 \\
\hline Озон-1,0 & 32,3 & 25,2 & 28,7 & 57,5 \\
\hline $\mathrm{HCP}_{0,5}$ & 0,97 & 1,71 & - & - \\
\hline
\end{tabular}

на 2,4 т/га, или на 8,7\%, чем в контрольном варианте. В 2017 году урожайность зелёной массы получена ниже, чем в 2016 году на всех вариантах опыта: в контроле - на 3,2 т/га, или на 10,4\%, Озон-0,5 - на 5,1 т/га, или 14,5\% и Озон-1,0 - на 7,1 т/га, или 22\%. В среднем за годы исследований В варианте Озон-0,5 рост урожайности составил 3,5 т/га, или 12,0\%, а в варианте Озон-1,0 - снижение урожайности на 0,5 т/га, или на 1,7\%, чем в контроле. Учитывая урожайность в сумме за два года, в варианте Озон-0,5 урожайность зелёной массы увеличилась на 7,1 т/га, или на 12,2\%, а в варианте Озон-1,0 снизилась на 0,9 т/га, или на 1,5\%, по сравнению с контролем.

В ходе исследований нами была проведена сравнительная экономическая эффективность выращивания клевера лугового в разных вариантах опыта [11].

Показатели эффективности выращивания клевера лугового сорта Сонет приведены в таблице 2.

Расчёты по определению эффективности разного режима озонирования показали, что в варианте Озон-0,5 затраты на выращивание зелёной массы клевера лугового увеличились на 510,78 руб./га, или на 4,8\%, а в варианте Озон1,0 - на 413,25 руб./га, или на 3,9\%, чем в контроле. Однако себестоимость полученной продукции в варианте Озон-0,5 была меньше на 23,23 руб./т, или на 6,4\%, а варианте Озон 1,0 - больше на 20,7 руб./т, или на 5,7\%, чем в контрольном варианте.

Таблица 2 - Влияние предпосевного озонирования семян на эффективность производства зелёной массы клевера лугового сорта Сонет (в среднем за 2016-2017 гг.)

\begin{tabular}{|l|c|c|c|}
\hline \multirow{2}{*}{ Показатель } & \multicolumn{3}{c|}{ Вариант } \\
\cline { 2 - 4 } & контроль & Озон-0,5 & Озон-1,0 \\
\hline Урожайность, т/га & 29,20 & 32,70 & 28,70 \\
\hline Затраты, руб./га & 10597,00 & 11107,78 & 51010,25 \\
\hline в т.ч. затраты на озонирование & - & 510,78 & 310,78 \\
\hline Себестоимость, руб./т & 362,91 & 339,68 & 383,61 \\
\hline
\end{tabular}




\section{Выводы}

1. Энергия прорастания при обработке семян озоновоздушным потоком при концентрации озона на уровне $0,8 \mathrm{mr} / \mathrm{M}^{3}$ и $1,5 \mathrm{mr} / \mathrm{M}^{3}$ была выше контрольного варианта на 13 и 10\% соответственно.

2. Лабораторная всхожесть по вариантам опыта составила в вариантах контроль, Озон-0,5 и Озон-1,0 - 87, 92 и 91\% соответственно.

3. Предпосевная обработка семян озоновоздушным потоком при концентрации озона на уровне $0,8 \mathrm{mr} / \mathrm{M}^{3}$ обеспечила повышение урожайности от 9,4 до $14,6 \%$, при концентрации $1,5 \mathrm{mr} / \mathrm{M}^{3}$ - до 4,8\% по сравнению с контролем.
4. В 2017 году была получена наивысшая урожайность зелёной массы клевера лугового в варианте Озон-0,5 - 32,7 т/га, что больше на 3,5 т/га, или на 11,9\%, чем в контроле.

5. Урожайность зелёной массы в среднем за два года в варианте Озон-0,5 была выше на 3,5 т/га, или на $11,9 \%$, а в варианте Озон-1,0 ниже на 0,5 т/га, или на 1,7\%, чем в контрольном варианте.

6. В среднем за 2016-2017 гг. в варианте Озон0,5 урожайность зелёной массы была выше на 4 т/га, или на 13,9\%, а себестоимость единицы продукции ниже на 43,93 руб./т, или на 11,5\%, чем на варианте Озон-1,0.

\section{תumepamypa}

1. Ткаченко, С.Н. О работе и деятельности семинара по озону и деятельности общественной организации Озонное общество - ассоциация «Озон и другие экологически чистые окислители» [Текст] / С.Н. Ткаченко, В.В. Лунин, В.А. Вобликова // Озон и другие экологически чистые окислители. Наука и технологии: материалы 32-го всеросс. семинара. - М.: Макспресс, 2012. - 200 с.

2. Авдеева, В.Н. Влияние обработки озоном на физиологические параметры пшеницы [Текст] / В.Н. Авдеева, Ю.А. Безгина, С.И. Любая // Научное обозрение. Сельскохозяйственные науки. - 2014. - № 1. - С. 9.

3. Нормов, Д. Озонирование повышает посевные качества семян [Текст] / Д. Нормов, А. Шевченко, Е. Федоренко // Сельский механизатор. - 2009. - № 1. - С. 14-15.

4. Васильчук, Н.С. Предпосевная обработка семян озоном [Текст] / Н.С. Васильчук, В.Б. Лебедев, С.М. Лисовский и др. // Современное растениеводство России: практика и научные достижения. - М.: Агро XXI, 2004. - № 7-12. - С. 67-68.

5. Баскаков, И.В. Применение процесса озонирования в сельском хозяйстве [Текст] / И.В. Баскаков, В.И. Оробинский, А.П. Тарасенко и др. // Вестник Воронежского государственного аграрного университета. - 2016. - №3 (50). - С. 120-125.

6. Пат. 2352521 Российская Федерация, С01В 13/11. Высокочастотный барьерный озонатор [Текст] / Тышкевич Е.В.; заявитель и патентообладатель ГНУ КНИИСХ. - № 2007132403/15, заявл. 27.08.07; опубл. 20.04.09, Бюл. № 11.

7. Майсурян, Н.А. Практикум по растениеводству [Текст] / Н.А. Майсурян. - М.: Колос, 1970. - 446 с.

8. Доспехов, Б.А. Методика полевого опыта [Текст] / Б.А. Доспехов. - 5-е изд., доп. и перераб. М.: Агропромиздат, 1985. - 351 с., ил.

9. Сорокин, А.Н. Влияние озонирования на посевные качества семян и урожайность клевера лугового [Текст] / А.Н. Сорокин, Т.М. Морозова // Современные наукоемкие технологии. Региональное приложение. - 2018. - № 3 (55) - С. 146-151.

10. Сорокин, А.Н. Влияние обработки озоновоздушным потоком на посевные качества семян зерновых культур [Текст] / А.Н. Сорокин // Актуальные проблемы науки в агропромышленном комплексе: сб. статей 68-й международ. науч.-практ. конф. - Т. 1: Агробизнес. Ветеринарная медицина и зоотехния / под ред. Ю.В. Панкратова, Н.Ю. Парамоновой. - Караваево: Костромская ГСХА, 2017. - С. 74-79.

11. Программа и методика расчёта технологических карт возделывания полевых культур [Текст]: методические указания / сост. Г.Б. Демьянова-Рой, Ю.В. Панкратов, А.Н. Сорокин. - Караваево: Костромская ГCXA, 2015. - 41 c.

\section{References}

1. Tkachenko, S.N. O rabote i dejatel'nosti seminara po ozonu i dejatel'nosti obshhestvennoj organizacii Ozonnoe obshhestvo - associacija «Ozon i drugie jekologicheski chistye okisliteli» [Tekst] / S.N. Tkachenko, V.V. Lunin, V.A. Voblikova // Ozon i drugie jekologicheski chistye okisliteli. Nauka i tehnologii: materialy 32-go vseross. seminara. - M.: Makspress, 2012. - $200 \mathrm{~s}$.

2. Avdeeva, V.N. Vlijanie obrabotki ozonom na fiziologicheskie parametry pshenicy [Tekst] / V.N. Avdeeva, Yu.A. Bezgina, S.I. Lyubaya // Nauchnoe obozrenie. Sel'skohozjajstvennye nauki. - 2014. - № 1. - S. 9. 
3. Normov, D. Ozonirovanie povyshaet posevnye kachestva semjan [Tekst] / D. Normov, A. Shevchenko, E. Fedorenko // Sel'skij mehanizator. - 2009. - № 1. - S. 14-15.

4. Vasil'chuk, N.S. Predposevnaja obrabotka semjan ozonom [Tekst] / N.S. Vasil'chuk, V.B. Lebedev, S.M. Lisovskij i dr. // Sovremennoe rastenievodstvo Rossii: praktika i nauchnye dostizhenija. - M.: Agro XXI, 2004. - № 7-12. - S. 67-68.

5. Baskakov, I.V. Primenenie processa ozonirovanija v sel'skom hozjajstve [Tekst] / I.V. Baskakov, V.I. Orobinskij, A.P. Tarasenko i dr. // Vestnik Voronezhskogo gosudarstvennogo agrarnogo universiteta. - 2016. - №3 (50). S. $120-125$.

6. Pat. 2352521 Rossijskaja Federacija, S01V 13/11. Vysokochastotnyj bar'ernyj ozonator [Tekst] / Tyshkevich E.V.; zajavitel' i patentoobladatel' GNU KNIISH. - № 2007132403/15, zajavl. 27.08.07; opubl. 20.04.09, Bjul. № 11.

7. Majsuryan, N.A. Praktikum po rastenievodstvu [Tekst] / N.A. Majsuryan. - M.: Kolos, 1970. - $446 \mathrm{~s}$.

8. Dospekhov, B.A. Metodika polevogo opyta [Tekst] / B.A. Dospekhov. - 5-e izd., dop. i pererab. M.: Agropromizdat, 1985. -351 s., il.

9. Sorokin, A.N. Vlijanie ozonirovanija na posevnye kachestva semjan i urozhajnost' klevera lugovogo [Tekst] / A.N. Sorokin, T.M. Morozova // Sovremennye naukoemkie tehnologii. Regional'noe prilozhenie. - 2018. № $3(55)$ - S. 146-151.

10. Sorokin, A.N. Vlijanie obrabotki ozonovozdushnym potokom na posevnye kachestva semjan zernovyh kul'tur [Tekst] / A.N. Sorokin // Aktual'nye problemy nauki v agropromyshlennom komplekse: sb. statej 68-j mezhdunarod. nauch.-prakt. konf. - T. 1: Agrobiznes. Veterinarnaja medicina i zootehnija / pod red. Yu.V. Pankratova, N.Yu. Paramonovoj. - Karavaevo: Kostromskaja GSHA, 2017. - S. 74-79.

11. Programma i metodika raschjota tehnologicheskih kart vozdelyvanija polevyh kul'tur [Tekst]: metodicheskie ukazanija / sost. G.B. Dem'yanova-Roj, Yu.V. Pankratov, A.N. Sorokin. - Karavaevo: Kostromskaja GSHA, 2015. - $41 \mathrm{~s}$.

\section{ОБЫЯВЛЕНИЕ}

\section{В издательстве ФГБОУ ВО Ярославская ГСХА в 2017 г. вышла монография}

\section{Р.В. Тамаровой, Н.Н. Канарейкиной}

\section{«ПОВЫШЕНИЕ ЭФФЕКТИВНОСТИ ИСПОЛЬЗОВАНИЯ МОЛОЧНОГО СКОТА НА КРУПНОМ КОМПЛЕКСЕ С БЕСПРИВЯЗНЫМ СОДЕРЖАНИЕМ КОРОВ॥}

В монографии представлен опыт создания высокопродуктивного племенного стада на базе товарного в условиях комплекса с беспривязным содержанием коров. Рассмотрены вопросы адаптации, здоровья и сохранности животных, причины выбытия их из стада, кормления и выращивания молодняка, молочная продуктивность, технологические качества, воспроизводительная способность, экономическая эффективность хозяйственного использования коров разных генетических групп, отечественной и импортной селекции. Исследования проводились с использованием научных методик и пакета компьютерных программ. Все количественные показатели биометрически обработаны, с выявлением достоверности разности при трёх уровнях вероятности. На основании полученных результатов сделаны обоснованные выводы и предложения производству.

Монография предназначена для руководителей и специалистов хозяйств, научных сотрудников институтов, аспирантов и студентов, обучающихся по специальности «Зоотехния».

УДК 636.2.034.:636.083.312.3; ББК 46.0; ISBN 978-5-98914-185-2; 148 стр.

ПО ВОПРОСАМ ПРИОБРЕТЕНИЯ ОБРАЩАТЬСЯ ПО АДРЕСУ:

150042, Г. ЯРОСЛАВЛЬ, ТУТАЕВСКОЕ ШОССЕ, 58, ФГБОУ ВО ЯРОСЛАВСКАЯ ГСХА e-mail: e.bogoslovskaya@yarcx.ru 